DOI: 10.17117/na.2016.11.03.303

Поступила (Received): 03.11.2016

\title{
Воробец Л.В.
}

\section{Репрезентация лексико-семантического поля концепта "Лень" в аспекте межкультурного сопоставления}

\author{
Vorobets L.V. \\ Representation of the lexico-semantical field of the concept \\ "Laziness" in the aspect of intercultural comparison
}

Статья посвящена рассмотрению лексикосемантического поля концепта "Лень" с точки зрения межкультурного сопоставления. Автором выявлены ядро и периферия анализируемого явления в английском, русском и китайском языках. Сформулированы выводы относительно общих и отличных черт исследуемого концепта

Ключевые слова: лингвокультура, концепт, межкультурная коммуникация, ядро, периферия

\section{Воробец Лариса Викторовна}

Кандидат культурологии, доцент

Краснодарское высшее военное авиационное училище летчиков им. А.К. Серова

г. Краснодар, ул. Дзержинского 135
The article is devoted to the analysis of the lexicosemantical field of the concept "Laziness" from the intercultural point of view. The author defines the core and the periphery of the object of the article in the Russian, English and Chinese languages. The conclusions are made about common and different features of the analyzed phenomenon

Key words: linguoculture, concept, intercultural communication, core, periphery

\section{Vorobets Larisa Victorovna \\ Candidate of Culturology, Associate Professor Krasnodar air force institute named A.K. Serova Krasnodar, Dzerzhinskogo st., 135}

Проблема взаимосвязи культуры и языка является одной из главных в языкознании. Воздействие культуры на язык очевидно, остается лишь открытым вопрос об обратном воздействии языка на культуру. Языковые единицы, которые обладают культурно-национальной спецификой, имеют свои способы ее отражения в языке, а мифологемы, концепты, стереотипы, символы, эталоны являются знаками общечеловеческой культуры. Языковые картины мира имеют как совпадения, так и различия, а поиски и обнаружение различий и сходств между этими картинами мира способствует улучшению межкультурного общения. Исследуемым объектом данной статьи является концепт «Лень» с точки зрения компаративистского подхода, который влечет за собой определенный ряд сравнений общих и различных черт указанного объекта в русской, английской и китайской лингвокультурах.

В толковом словаре В. Даля даются следующие определения понятия «лень»: 1) неохота работать; 2) отвращение от труда, от дела, от занятий; 3) наклонность к праздности, к тунеядству $[1,102]$. В словаре Д.Н. Ушакова мы 
встречаем следующие дефиниции: 1) отсутствие желания работать; 2) нелюбовь к труду; 3) отсутствие желания делать, что бы то ни было [4, 153]. В словаре С.И. Ожегова приводятся определения, синонимичные приведенным выше, и добавлено еще одно: склонность к безделью $[3,76]$. С.А. Кузнецов предлагает еще одно объяснение данного феномена, а именно состояние вялости, сонливости и апатии $[2,98]$. Можно сделать вывод, что в русском языке самым распространенным определением понятия «лень» является отсутствие желания работать.

Дефиниционное описание концепта «лень», основанное на данных словарей, позволяет нам выделить семантическое поле концепта «лень», разнообразное в семантическом отношении и достаточно четко структурируемое. Ядром поля является существительное «лень», фиксируемое во всех лексикографических источниках. Концепт «лень» в русском языке является многогранным и полновесным явлением, образуя семантическое поле. Ядром этого поля можно считать лексему «лень», а к периферии относить «бездействие» и «безделье».

В английском языке понятие «лень» обозначается словом «laziness». Bo время исследования были найдены следующие определения данного понятия. Согласно словарю «Oxford Dictionary» «laziness» это «the quality of being unwilling to work or use energy» (состояние нежелания работать и тратить энергию). Словарь «Webster's Revised Unabridged Dictionary» дает следующее определение: «the state or quality of being lazy» (состояние лености). Словарь «MerriamWebster» предлагает следующую трактовку: «an inclination not to do work or engage in activities» (предпочтение не работать или заниматься деятельностью) [6].

В ходе исследования в различных источниках были найдены следующие синонимы к слову «laziness» - indolence, inertia, inactiveness, inactivity, faineance, idleness, shiftlessness, acedia, sloth, do-nothingness. Можно отметить, что синонимов понятия «лень» в английском языке гораздо больше, чем в русском. Сравнив частотность употребления, было выявлено несколько доминантных дефиниций: indolence, idleness, inactivity. Согласно словарю «Oxford Dictionary» indolence это «avoidance of activity or exertion; laziness» (избегание деятельности или усилий, лень). Также в словаре «Collins Dictionary» дается следующее определение «indolence means laziness» [5]. Как мы видим, indolence является прямым, взаимозаменяемым синонимом слова laziness. Кроме того, словарь «Oxford Dictionary» дает следующее определение: «idleness is a state of inaction; inactivity; laziness; indolence», что опять показывает близость слов по значению. Все эти синонимы могут быть взаимозаменяемы, и это не влияет на смысл предложения.

Таким образом, можно сделать вывод, что ядром семантического поля является лексема «laziness», а к периферии относятся «indolence», «idleness», «inactivity».

В китайском языке концепт «лень» обозначается двумя иероглифами «蕒 惰», и согласно словарю ABВYY Lingvo означает лень, ленивый, леность [7]. На сайте БКРС (большой китайско-русский словарь) дается следующее толкование концепта 《懶惰》: 《偷懒; 不喜欢费体力或脑力» [8]. Данное определение можно перевести следующим образом: «ленивый; не любит физические и умственные нагрузки». Дугой ресурс Hudong.com, который является китайским аналогом русской Википедии, предлагает следующее определение:《不爱劳动和工作；不 
勤快。懒惰是一种心理上的厌倦情绪。它的表现形式多种多样，包括极端的懒散状 态和轻微的犹豫不决。生气、羞怯、嫲妒、嫌恶等都会引起懒惰，使人无法按照自 已的愿望进行活动》 («Не любовь к труду или работе; неисполнительный. Лень это физическая усталость. Ее проявления разнообразны и включают крайнюю апатию и небольшое состояние нерешительности. Гнев, застенчивость, зависть, отвращение, и это приведет к ленивым людям, которые не могут осуществлять деятельность в соответствии с их пожеланиями»).

В ходе анализа были найдены следующие синонимы исследуемого явления в состав которых входит «情»: 怠惰 dàiduò (ленивый, нерадивый; распущенный, небрежный); 惰慢 duòmàn (лениться; ленивый; небрежный, беспечный; лень); 懈惰 хіѐduò( лениться, быть ленивым (неповоротливым, инертным); инертность, лень); 窊惰 yǔduò (лениться; лень; неисправимо ленивый); 隋惰 huīduò (ленивый, распущенный; лень, разгильдяйство). Синонимы, в состав которых входит «懶»: 懒于 lănyú (лениться; лень что-либо делать); 懒动 lăndòng (лень с места сдвинуться; ленивый); 懒总 lăndài (лениться; неохотно; лень); 懒 性 lănxìng (леность, лень). Кроме того, существует большое количество синонимов, не имеющих никаких общих иероглифов. Например, 懈倦 хіѐjuàn (нерадивость, лень; лениться); 淫总 yíndài (распущенность и лень; ленивый до безобразия). Ядром семантического поля является лексема «懶惰》, а к периферии относятся лексемы 懒总 lăndài, 怠惰 dàiduò.

Таким образом, можно сделать вывод, что приведенные выше русские, английские и китайские дефиниции концепта «лень», их описание и синонимы, доказывают то, что под «ленью» в анализируемых лингвокультурах понимают, прежде всего, «нежелание работать и бездеятельность». Кроме того, «лень», «laziness» и «懶惰》 являются доминантами синонимичных рядов, что доказывает их высокую частотность употребления и полисемичность.

\section{Список используемых источников:}

1. Даль В. Толковый словарь живого великорусского языка. М.: ОЛМА-ПРЕСС, 2002. 231 c.

2. Кузнецов С.А. Большой толковый словарь русского языка. СПб: Норинт, 2000. 363 c.

3. Ожегов С.И. Словарь русского языка. М.: 1972.115 с.

4. Ушаков, Д. Н.Толковый словарь русского языка. М.: Русские словари, 1996. 213 с.

5. Collins // collinsdictionary.com: Web-словарь. 2006. URL: http://www.collinsdictionary.com

6. Merriam-Webster // merriam-webster.com: Web-словарь. 2007. URL: http://www.merriam-webster.com

7. Давид, Я. Электронный словарь Lingvo. М.: АВВYY, 1996 - 2010.

8. БКРC // bkrs.info: Web-словарь. 2004. URL: http://www.http://bkrs.info

(C) 2016, Воробец л.в.

Репрезентация лексико-семантического поля концепта "Лень" в аспекте межкультурного сопоставления (c) 2016, Vorobets L.V.

Representation of the lexico-semantical field of the concept "Laziness" in the aspect of intercultural comparison 